\title{
A Study on the Changes in the Land Use Paradigm in the Era of the 4th Industrial Revolution - Focus on the Effective Use and Commercialization of Damaged Areas in Development Restriction Area
}

\author{
Jaehwan $\mathrm{Kim}^{1 *}$ and Heecheol Shim ${ }^{2}$ \\ ${ }^{1}$ Associate Professor, Major in Real Estate Studies, Faculty of Regional Development, \\ Kongju Nat'l University. Yesan, Chungnam, South Korea \\ ${ }^{2}$ Local Investment Management Center, Korea Research Institute for Local \\ Administration, Nambusunhwanro, Seochogu, Seoul, South Korea \\ jaehwan@kongju.ac.kr, ${ }^{2}$ sim12@krila.re.kr
}

\begin{abstract}
This study suggests a business model for the maintenance and utilization of the damaged areas in the development restricted areas of Korea and suggests the most effective use of land use for them. The contents of the proposal are as follows: (1) economic efficiency due to the establishment of a solar-based warehouse combining environmentally friendly energy technologies; and (2) economic efficiency due to the provision of mobile homes (modular housing) to improve housing welfare of low-income households. Finally, even if the land lacks business feasibility in accordance with the institutional purpose of the damaged land maintenance project, it is necessary to purchase damaged land positively to prevent further damage and to link the land cost festival to preserve the future value.
\end{abstract}

Keywords: Urban regeneration project, Empty house, Utilization methods, Regional classification, Sustainability

\section{Introduction}

The damage to the restricted area of development is illegally converted after unauthorized licensing and used for warehouses, factories, and workplaces. This means that the profit from leasing illegal buildings is less than the amount due for the compulsory execution of illegal acts This is because it is caused by a large number of people. According to a report by the Ministry of Land, Transport and Maritime Affairs in Korea in 2013, about $70 \%$ of the respondents who said that illegal activities persist in a survey of local government officials are "It is because it is profitable even if payment of the transition compulsory gold is paid". It can be seen that "the residents or the landowners are illegally developing illegal activities". To improve the efficiency of land use by the 4th Industrial Revolution era, the Ministry of Land, Transport and Maritime Affairs By introducing the gold system, economic sanctions against illegal gains are taken to prevent the occurrence of illegal activities. It is a fact that it is being raised. Therefore, this study suggests a business model for the maintenance and utilization of the damaged areas in the development restricted areas of Korea and suggests the most effective use of land use for them.

Article history:

Received (March 9, 2019), Review Result (April 4, 2019), Accepted (May 5, 2019) 


\section{Theoretical background}

\subsection{Preliminary study on the living environment of residents in the restricted area}

Previous studies have also been actively pursuing a plan to purchase land in the restricted area for permanent preservation[1][2]. We sought the conservation measures of developed countries that were introduced earlier than Korea in terms of the institutional system. In Korea, there are difficulties in introducing and implementing such a system, but the nationalization plan, the aspect of environmental preservation, and subsidies [3].

\subsection{Preliminary study on conflicts in the restricted area}

Most of the studies on the green belt have focused on assessing the effectiveness of the Green Belt [4]. The analysis of the land and housing prices in the green belt, the social benefits and cost estimates of the green belt, and the impact of the designation of the Green Belt on the urban spatial structure was a major theme. The survey also analyzed the public's understanding of the green belt system and the willingness of the residents to pay for it [5]. In addition, in the analysis of cognition and analysis on the restricted area management system, we analyzed the complaints and officials about the restricted area in Seoul [6]. In the analysis of expert's recognition about the restricted area management system, 13 types presented in the civil service survey analysis were suggested through the expert questionnaire and civil servant workshop.

\section{Connecting urban regeneration with local universities commercialization of land use by alternatives}

\subsection{Assumption of the economic feasibility study}

In the case of public sector feasibility studies, public and public buildings have the characteristics of public goods, so they should analyze the economic benefits as seen from the national economic perspective as well as the financial analysis utilized in the private sector.

Table 1. Financial feasibility vs. financial feasibility economic feasibility

\begin{tabular}{|c|c|c|}
\hline Item & Financial feasibility & Economic feasibility \\
\hline Target & $\begin{array}{c}\text { Financial net present value } \\
\text { measurement }\end{array}$ & Social net present value measurement \\
\hline $\begin{array}{c}\text { Preparation of } \\
\text { financial statements }\end{array}$ & Cash inflow - cash outflow & Social benefits - social costs \\
\hline $\begin{array}{c}\text { Income and loss } \\
\text { inclusion rules }\end{array}$ & Cash Flow 100\% & $\begin{array}{c}\text { Social impact 100\% } \\
\text { (Direct or indirect, non-existent) }\end{array}$ \\
\hline Positive variable & $\begin{array}{c}\text { Annual cash inflow } \\
\text { (Denominated in monetary unit) }\end{array}$ & $\begin{array}{c}\text { Sum of consumer paying physicians } \\
\text { (Social benefits) }\end{array}$ \\
\hline $\begin{array}{c}\text { Negative variable } \\
\text { Annual cash outflow, initial } \\
\text { investment cost }\end{array}$ & $\begin{array}{c}\text { Social opportunity costs and initial investment } \\
\text { costs by year of resource consumption }\end{array}$ \\
\hline $\begin{array}{c}\text { Valuation of income } \\
\text { and loss }\end{array}$ & $\begin{array}{c}\text { Evaluate with a present value under } \\
\text { current market conditions }\end{array}$ & $\begin{array}{c}\text { Evaluate to competitive potential prices } \\
\text { calculated from ideal market conditions }\end{array}$ \\
\hline
\end{tabular}

The feasibility analysis method is generally based on the value of input and output using the benefit/cost ratio method $(\mathrm{B} / \mathrm{C})$, the net present value method, the internal rate of return method, the payback period method, and the ROI. The cost-benefit ratio is a method to judge the 
feasibility of the business by converting the total benefits and the total cost into the present value.

\subsection{Commercialization plan}

\subsubsection{Construction of warehouse using solar facilities}

In the case of public sector feasibility studies, public and public buildings have the characteristics. Development of warehouse facilities in connection with the renewable energy supply project of the Korea Land \& Housing Corporation's Construction Technology Headquarters. This can be implemented for recovery of green space function and improvement of the urban environment by permitting installation of legitimate logistics warehouse for existing use. The premise of the analysis is based on the average land area and the coverage rate in the application area of the application case and estimated the approximate project cost assuming the following assumption to be about 8.4 billion.

Table 2. Estimation of warehouse composition using the photovoltaic facility

\begin{tabular}{|c|c|c|c|c|}
\hline Distribution & A site & B site & Total & Court \\
\hline Local district & \multicolumn{4}{|c|}{ Natural greenery / GB } \\
\hline Site area $\left(\mathrm{m}^{2}\right)$ & 5,719 & 3,654 & 9,373 & \\
\hline Building area $\left(\mathrm{m}^{2}\right)$ & 2,994 & 2,023 & 5,017 & \\
\hline Coverage ratio & 52.36 & 55.38 & 53.53 & $60 \%$ or less \\
\hline Total floor area & 5,979 & 4,037 & 10,017 & \\
\hline Floor area ratio & 104.55 & 110.50 & 106.87 & $120 \%$ or less \\
\hline $\begin{array}{l}\text { Number of } \\
\text { parking spaces }\end{array}$ & 16 & 12 & 28 & $\begin{array}{c}22 \\
\left(400 \mathrm{~m}^{2} / \text { more than } 1 \text { unit }\right)\end{array}$ \\
\hline Highest height & 7.90 & 7.90 & - & $8 \mathrm{~m}$ or less \\
\hline structure & \multicolumn{4}{|c|}{ Iron frame } \\
\hline Number of floors & \multicolumn{4}{|c|}{2 stories above ground } \\
\hline Usage & \multicolumn{4}{|c|}{ warehouse } \\
\hline \multirow{4}{*}{ Building cost } & Unit price per py & $1,682,222(\mathrm{KRW})$ & $\begin{array}{c}1,682,222 \\
(\mathrm{KRW})\end{array}$ & \multirow{4}{*}{$\begin{array}{c}\text { Office: Office and cosmetic area } \\
\text { Floor area: Floor area } \\
\text { Average floor height: } 1 \text { st-floor } \\
\text { factory } 9 \mathrm{~m} / 2 \text { nd-floor window } \\
5 \mathrm{~m} \\
\text { Outer wall: Euro zinc panel } \\
\text { (150T, KS foam) } \\
\text { Sloped Roof (Zinc): Zinc Panel } \\
\text { (260T) } \\
\text { Chang-ho: Corporation: }\end{array}$} \\
\hline & $\begin{array}{l}\text { Office building } \\
\text { cost }\end{array}$ & $\begin{array}{l}50,000,000 \\
(\mathrm{KRW})\end{array}$ & $\begin{array}{c}30,000,000 \\
(\mathrm{KRW})\end{array}$ & \\
\hline & $\begin{array}{c}\text { Roof construction } \\
\text { cost }\end{array}$ & $\begin{array}{c}54,360,000 \\
(\mathrm{KRW})\end{array}$ & $\begin{array}{l}36,720,000 \\
(\mathrm{KRW})\end{array}$ & \\
\hline & Construction cost & $\begin{array}{l}3,014,604,060 \\
\quad(\mathrm{KRW})\end{array}$ & $\begin{array}{l}2,976,964,060 \\
(\mathrm{KRW})\end{array}$ & \\
\hline $\begin{array}{c}\text { Solar installation } \\
\text { cost } \\
\end{array}$ & $\begin{array}{l}\text { Per KW (1 } \\
\text { pyeong) }\end{array}$ & $1,250,000(\mathrm{KRW})$ & $\begin{array}{c}\text { 3,294,588,299 } \\
(\text { KRW })\end{array}$ & $\begin{array}{c}\text { Reflecting the whole building } \\
\text { area }\end{array}$ \\
\hline \multirow[b]{2}{*}{ Compensation fee } & $\begin{array}{l}\text { Purchase of land } \\
\text { (purchase of } \\
\text { scattered debris) }\end{array}$ & \multicolumn{2}{|c|}{ 2,135,700,000 (KRW) } & \multirow{2}{*}{$\begin{array}{l}\text { The obstacle is due to the } \\
\text { valuation in accordance with the } \\
\text { provisions of the Law on } \\
\text { Acquisition and Compensation } \\
\text { of Land for Public Service }\end{array}$} \\
\hline & $\begin{array}{c}\text { Compensation } \\
\text { water } \\
\text { compensation } \\
\text { (building, interior) }\end{array}$ & \multicolumn{2}{|l|}{-} & \\
\hline
\end{tabular}




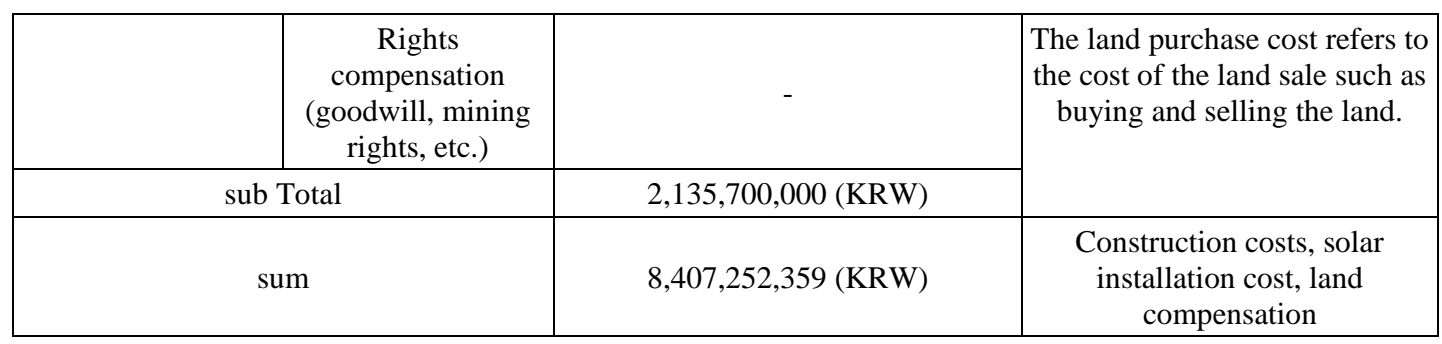

We analyzed NPV, IRR, and BC based on the initial investment cost versus the initial investment cost during the operating period. To calculate the operating profit, the warehouse rent in Gyeonggi province was surveyed (rental deposit and rent). In this analysis, $6.5 \%$ of the current rental deposit conversion rate was assumed and the warehouse rent per $\mathrm{m}^{2}$ was calculated as 8,598 Won). The initial investment cost of the project estimated using the photovoltaic facility is $8,407,252,668$ won, the initial annual operating profit is $898,968,236$ won, the operating cost assumes $40 \%$ of the operating profit, assuming a $2 \%$ raise every year, depreciation is based on a 40 -year straight-line method and a $4.5 \%$ social reduction rate. The initial investment cost of the project estimated using the photovoltaic facility is 8,407,252,668 won, the initial annual operating profit is $898,968,236$ won, the operating cost assumes $40 \%$ of the operating profit, assuming a $40 \%$ straight-line depreciation and a $4.5 \%$ social reduction rate, the NPV is KRW 1,062,017,379), IRR is 5,23\%, and BC is 0.75 .

\subsubsection{Construction of mobile public rental housing (modular housing) for low-income families}

The Public Housing Division of Korea Land \& Housing Corporation is actively promoting the mobile public rental housing business. This project is a new concept of public rental housing business that removes the old housing of low-income households who cannot repair the house in the city and builds and supplies modular housing. Modular housing makes $70 \sim 80 \%$ It is a type of industrialized housing that is assembled in the field. It can secure homogeneous housing quality through mechanized production and it is possible to supply quickly. In particular, according to the roadmap for housing welfare, this project can provide a way of providing stockpiles of modular housing as a business model for supplying emergency housing to lowincome households that need temporary housing in an unfavorable situation. The premise of the analysis is based on the average land area and the coverage rate in the application area of the application case, and the estimated project cost is about 7.3 billion.

Table 4. Modular housing project cost

\begin{tabular}{|c|c|c|c|c|}
\hline Distribution & History & & Cost & Remarks \\
\hline Local district & \multicolumn{4}{|c|}{ Natural greenery / GB } \\
\hline Site area $\left(\mathrm{m}^{2}\right)$ & \multicolumn{2}{|l|}{9,373} & & \\
\hline \multirow[t]{3}{*}{$\begin{array}{l}\text { Building area } \\
\qquad\left(\mathrm{m}^{2}\right)\end{array}$} & \multicolumn{2}{|l|}{5,017} & & \\
\hline & Moving Installation Cost & $49,500(\mathrm{KRW})$ & $248,341,500(\mathrm{KRW})$ & \\
\hline & subTotal & & $5,215,171,500(\mathrm{KRW})$ & \\
\hline $\begin{array}{l}\text { Compensation } \\
\text { fee }\end{array}$ & $\begin{array}{c}\text { Land purchase cost } \\
\text { (Purchasing scattered } \\
\text { debris) }\end{array}$ & $2,135,7$ & 700,000 (KRW) & $\begin{array}{l}\text { The obstacle is due to the } \\
\text { valuation in accordance } \\
\text { with the provisions of the }\end{array}$ \\
\hline
\end{tabular}




\begin{tabular}{|c|c|c|c|}
\hline & $\begin{array}{c}\text { Obstacle compensation fee } \\
\text { (Buildings, trees, etc.) }\end{array}$ & - & $\begin{array}{c}\text { Law on Acquisition and } \\
\text { Compensation of Land for } \\
\text { Public Service } \\
\text { The land purchase cost } \\
\text { refers to the cost of the } \\
\text { (Goodwill, mining rights, } \\
\text { etc.) }\end{array}$ \\
\hline sub Total & $2,135,700,000(\mathrm{KRW})$ & $\begin{array}{c}\text { Reward sale such as buying } \\
\text { and selling the land. }\end{array}$ \\
\hline sum & $7,350,871,500(\mathrm{KRW})$ & \\
\hline
\end{tabular}

The future economic benefits of modular housing (mobile housing) were analyzed by NPV, IRR, and BC based on the initial investment cost versus operating profit during the operating period. To calculate the operating profit, we surveyed rents of public rental housing (private supply standard) in Gyeonggi province. In this analysis, assuming pure monthly rent only, 6.5\% And the result is 11,071 (won). The initial investment cost of the modular housing construction project cost is 7,350,871,500 won. The initial annual operating profit is calculated based on the characteristics of the modular housing, and the quality of the housing is different from that of the public rental housing (private supply standard) (Private supply standard) Reflecting the $90 \%$ level of quality, the rent per $\mathrm{m} 2$ of modular housing was estimated at 10,286 won.

\subsubsection{Purchase of damaged land for lack of business and preservation of future value}

Given the institutional intent of the damaged land maintenance project, it is necessary to actively review land to avoid further damage by purchasing damaged land and to preserve its future value even if the land lacks business capability.

\section{Conclusion}

In this study, the concept of alternatives for the damaged areas in Korea was examined in four dimensions. The premise of the analysis was limited to the extent that it could be linked with the existing projects of the Korea Land Corporation 6 based on the average criteria. The results of the analysis are as follows: First, as a result of estimating the economic feasibility of the solar-based warehouse incorporating eco-friendly energy technology, it is judged that the net present value is higher than the social return rate of $4.5 \%$, on the other hand, the $\mathrm{BC}$ analysis was smaller than 1, but it was estimated at the level not considering the ripple effects of the local economy. Second, as a result of estimating the economic feasibility of mobile housing (modular housing) supply to improve the housing welfare of low-income households, the internal rate of return was $5.65 \%$, which was much higher than the $4.5 \%$, But the $\mathrm{BC}$ analysis is below 1, and the $\mathrm{BC}$ figure is expected to rise if we reflect various levels of future benefits. Finally, even if the land lacks business feasibility in accordance with the institutional purpose of the damaged land maintenance project, it is necessary to purchase damaged land positively to prevent further damage and to link the land cost festival to preserve future value.

\section{References}

[1] J. Yeong, I. Ho, and J. Yeong, "The Korea spatial planning review. A study on the development methods of the clustered settlement in the green belt: Focus on application of replotting method and land expropriation method in Gyeonggi province,” Korea Research Institute for Human Settlements, vol.84, pp.3-21, (2015)

[2] J. Yang and Dae, "The study about an analysis of damaged states of green belt," Hanyang University Graduate School of Master Thesis, Seoul (2011) 
[3] K. Jung, L. Eun, and J. Min, "A study on the revitalization of the settlement of development restricted areas," National Territory Policy Brief 590, Sejong, (2016)

[4] K. Jeong and Su, "A study on the effective use and management of land in accordance with the cancelation and adjustment of restricted development zone: Centering around restricted development zone within the city of Busan and its peripheral area," Dongeui University Graduate School of Master Thesis, Busan (2003)

[5] Korea Environment Institute, "Sustainable management of green belt by changing land environment management," Sejong, (2013)

[6] Korea Land \& Housing Corporation, "A study on the restoration plan of damaged land in the development restricted area and the management plan of the neighborhood area," Korea Land \& Housing Corporation, Jinju (2009). 


\section{Authors}

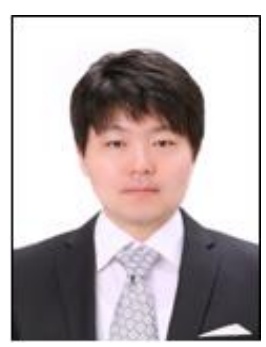

\section{Dr. Jaehwan, Kim}

$\mathrm{He}$ is an associate professor at the Department of Regional development, Kongju Nat'1 University, South Korea. His research interest is mixed-use development, feasibility study, and decision-making methodology.

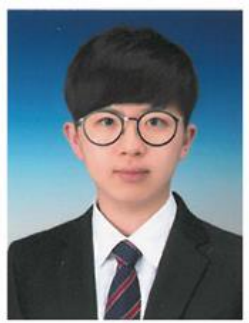

\section{Mr. Heecheol, Shim}

$\mathrm{He}$ is an analyst at the Local Investment Management Center, Korea Research Institute for Local Administration, South Korea. His research interest is project financing, feasibility study, and decision making in the local investment project. 
A Study on the Changes in the Land Use Paradigm in the Era of the 4th Industrial Revolution - Focus on the Effective Use and Commercialization of Damaged Areas in Development Restriction Area

This page is empty by intentions. 